\title{
THE COMPENSATION OF DISTRUPTIONS IN THE DISTRIBUTION CENTRE
}

\author{
Marzena KRAMARZ ${ }^{*}$, Mariusz KMIECIK ${ }^{2}$ \\ ${ }^{1}$ Politechnika Śląska, Zabrze; makram5@wp.pl \\ ${ }^{2}$ Politechnika Śląska, Zabrze; mariuszkmiecik93@gmail.com \\ * Correspondence author
}

\begin{abstract}
Disruptions occur in all distribution centres which work in nowadays market and participle in processes connected with goods flows. Due to this, the skill of detecting and dealing with disruptions is a very important issue. Disruptions could make impossible to correct actions of processes and have disaster financial or organisational effects. Distribution centres should look for and implement methods to effect disruption reducing, so they should improve their resistance. Article includes distribution centres description in the perspective of their meaning of disruptions compensation nodes in distribution network. Interpreting the concept of disruptions starts with the problem of compensation, resistance and risk and risk factors of disruptions. Main goal of article is a conceptualization of disruptions compensation model for regional distribution centre. Proposed disruptions identification and analysis procedure includes elements such as: diary method, disruption measurement card, FMEA, weighted average and Ishikawa Diagram. Procedure should be used for identification, measurement and propose preventive actions for all types of distribution centres.
\end{abstract}

Keywords: compensation, disruptions, distribution centre, resistance.

\section{Introduction}

Dealing with disruption is an extremely important thing for all organisations which are cooperating in supply chains and networks. In distribution networks, disruptions created in one of entity have a negative effect in all nodes cooperating in network, not even in organisation which has created it. One of methods to dealing with disruptions is a compensation of disruptions. It causes improve the level of resistance of logistics system.

Article focuses on showing the role of distribution centre in the compensation of disruption in the distribution network. Therefore, the interpretation and classification of disruption was showed. It also, by analysing an effects and reduction methods of disruptions, problems of improving resistance and compensation of disruption was considered. Article goal focuses on conceptualization of disruptions compensation model in the distribution 
centre and elaboration of disruptions identification and analysis procedure in these types of entities. Therefore, the entity was described and next the results of researches and universal procedure was showed.

\section{Distribution centre as a network node}

Distribution centres are the one of middleman in goods distributions. According to acceptance of property rights classification (Bendkowski, Kramarz, and Kramarz, 2010, p. 149) distribution centres are characterized by 2 factors: they participate in goods flows and they don't have property rights of distributed goods. Distribution centres was defined as: separate entities, which are providing services for manufacturing and trading companies. All operations connected with goods distributions are mainly provided by this same company, which transfers goods to a lot of entities (Barcik, 2005, p. 160-161). Additionally, distribution centres are an element of logistics point infrastructure. Distribution centre includes: lands and buildings, equipment, management and working teams, hardware and software, procedures and operational methods (Baker, 2008, p. 15). It could specify 3 basic distribution centres types (table 1).

Table 1.

Types of distribution centres

\begin{tabular}{|l|l|}
\hline \multicolumn{1}{|c|}{ Type } & \multicolumn{1}{c|}{ Characteristic } \\
\hline \multirow{4}{*}{ International Logistics Distribution Centres } & Area: $100-150 \mathrm{ha}$ \\
& Range: $500-800 \mathrm{~km}$ \\
& IT system: fully developed \\
& Logistics services: fully developed \\
\hline \multirow{3}{*}{ Regional Logistics Distribution Centres } & Area: $20-50 \mathrm{ha}$ \\
& Range: $50-80 \mathrm{~km}$ \\
& IT system: average \\
& Logistics services: chosen services \\
\hline \multirow{2}{*}{ Local Logistics Distribution Centres } & Area: $2-10 \mathrm{ha}$ \\
& Range: $5-8 \mathrm{~km}$ \\
& IT system: limited \\
& Logistics services: limited \\
\hline
\end{tabular}

Adapted from: "Logistyka dystrybucji” by R. Barcik. Copyright 2005 by ATH, p. 162.

Every type of distribution centre with tab 1 needs to fulfil varied functions. These functions are for example: goods flows managing according to customer needs, choosing the optimal carriers, cooperating the forwarding and logistics companies, using an infrastructure equipment, developing the integrated logistics systems, spreading the EDI and using advanced IT systems (Barcik, 2005, p. 161). Categories which are important for all centres, and which all centres should track and check all the time could divided into 8 groups (Robinson, 2017): 
- delivery on time - connected with right using of transportation equipment and correctly fulfilling distribution plans,

- accurate order fulfilment - mainly connected with proper goods commission processes in the warehouses,

- warehouse capacity monitoring - connected with avoiding of warehouse work overloads or too many supplies,

- define a peak of warehouse capacity - it is a point where exceeding causes operational plans failure,

- supply cycle times and internal processes connected with warehouse activities,

- annually workers rotation - connected with the quantity of experienced employees,

- goods reception time - connected with the time from arrival of cargo to locate cargo in particular places in warehouse,

- percentage damaged goods - connected with cargo loses in both: warehousing and transportation processes.

Important role, in distribution centres, takes also factors connected with characteristics of its activities, surrounding and internal processes. It could be for example: characteristics of stocks, centres assortment, type of used loading units, economic conditions, quantity of goods receipt and release in distribution centre, geographical location, selling possibilities and customers or suppliers requirements (Śliwczyński, 2008, p. 132-133). Additionally, among these factors could be: customers and assortment analysis and definition, establish distribution centre capacity, potential goods and information flows analysis, choosing the location, consideration of using an outsourcing in some areas (Jezusek, and Widera, 2001, p. 16-17).

Good flows in distribution networks, where distribution centres are included, is possible by effective order fulfilment system. Customers order fulfilment includes 4 stages (Grabowska, 2008, p. 34). First stage consists of submitting an order by entity. Mainly it is done electronically, by using EDI. Second stage focuses on forming an information and sending it to the warehouse. In the warehouse takes place third and fourth stages. There are: preparing goods and sending them to the customer. This process is showed in the fig. 1. 


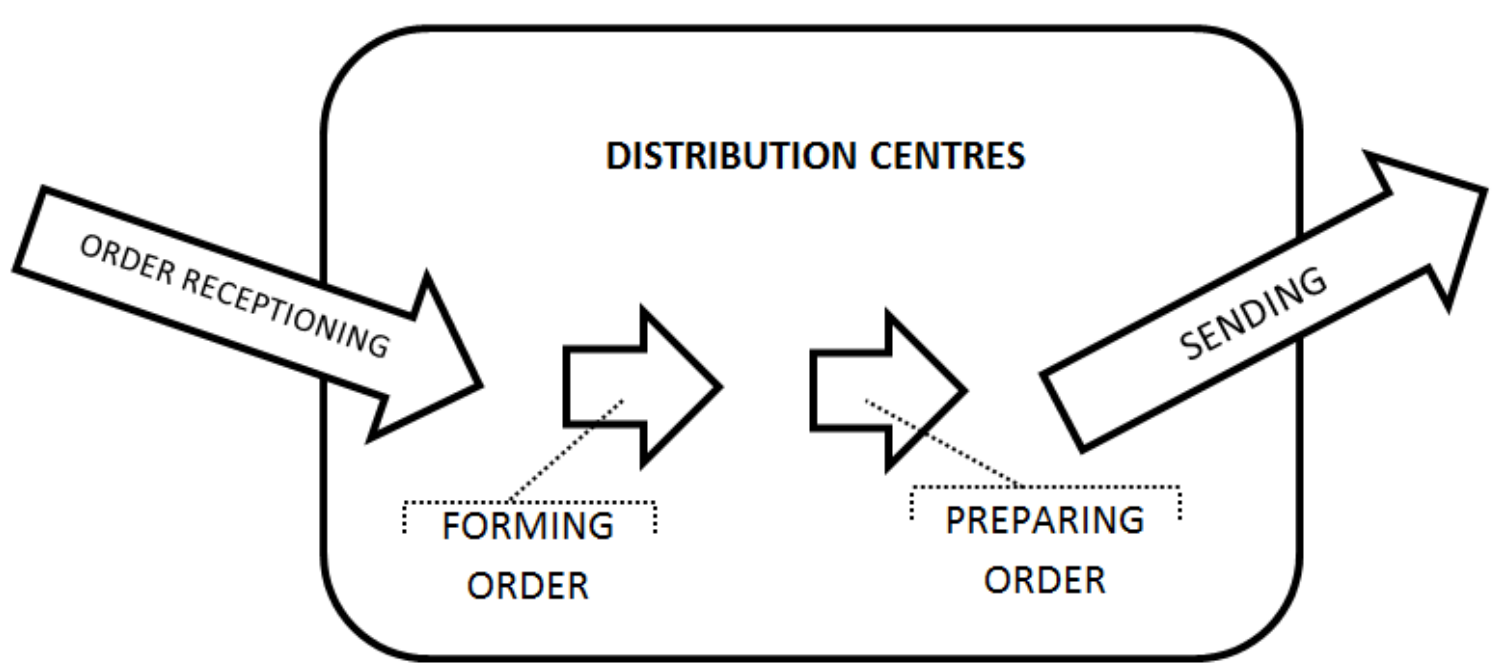

Figure 1. Order fulfilment process in distribution centre. Own elaboration based on: "Wpływ funkcjonowania centrum logistycznego na modernizację kanałów dystrybucji" by J. Grabowska. Copyright 2008 by Politechnika Śląska, p. 35.

Like is showed in fig. 1, all process stages occur chronologically and quality of one tasks has influence to quantity of final result. Efficiency of distribution centres could be measured by following indicators: financial (ex. repair costs), utilization (ex. percentage goods utilization), quality (percentage of good deliveries) or cycles time (Baker, 2007, p. 14). Besides mentioned indicators companies take a lot of different activities connected with satisfaction of final customer. It could be: internal warehouse transportation processes or placing orders. Characteristic features for this kind of objects are used tools (ex. EDI, MRP II, ERP, WMS), served customers area, infrastructure, average stocks indicator and efficiency of transportation and warehousing processes. Among elements which could improve centres activities there are for example: activities connected with VMI implement in centres, automatic IT technologies, reducing unnecessary warehousing movements, implement technologies aimed at warehousing processes optimization, for example: voice control, radio frequency (Harps, 2005). Therefore, one of the most important issue in distribution centres is their warehouse system, because majority of mentioned elements is concentrated within this area. Conditions, which have influence on warehouse system in distribution centres are showed in table 2.

Table 2.

Analysis of warehousing system conditions in distribution centres

\begin{tabular}{|c|c|}
\hline Condition & Characteristics \\
\hline Quantitative storage program & $\begin{array}{l}\text { Includes following data: } \\
\text { - type and form of stocks, } \\
\text { - type of used load units, } \\
\text { - max. warehouse capacity and level of safety stocks. }\end{array}$ \\
\hline Occupied warehouse space & $\begin{array}{l}\text { Includes: } \\
\text { - working space of warehouse, } \\
\text { - } \quad \text { warehouse volume. }\end{array}$ \\
\hline
\end{tabular}




\begin{tabular}{|l|l|}
\hline Operating cycle time & $\begin{array}{l}\text { Includes: } \\
\bullet \quad \text { time of operational and transportation cycles, } \\
\text { reloading and picking times. }\end{array}$ \\
\hline Type and quantity of used technical staff & Measures based on daily effort of technical fixed assets. \\
\hline Number and qualifications of employees & Includes employees which are working in the warehouse. \\
\hline Investment costs & Includes circulation on warehouse fixed assets. \\
\hline Operating costs & $\begin{array}{l}\text { Includes wearing-out the materials, buildings and warehouse's } \\
\text { devices. }\end{array}$ \\
\hline
\end{tabular}

Note. Own elaboration based on: "Planowanie logistyczne" by B. Śliwczyński. Copyright 2008 by Biblioteka Logistyka, p. 138-139.

Precise analysis of conditions from table 2 allows to fully use of distribution centre capabilities. Distribution centres allow to company better using transportation, warehouse, distribution processes (Barcik, 2005, p. 160). These benefits, in the literature, are extended by following factors (Bendkowski, and Kramarz, 2011, p. 275):

- centralization in the range of distribution control in one organizational structure,

- better matching transportation and warehouse systems to the infrastructure,

- using and perfecting IT systems,

- reaching benefits by using the scale economy.

Among main distribution centres strategies there are: postponement, delay the finish shape of products to reach the best personalization customer services, cross docking - stopping cargo only to reload to different kind of vehicle, without warehousing and using the third-part logistics to processes rationalization (Baker, 2008, p. 9-11). The most profitable situation is when the enterprise has a lot of dispersed customers. In this situation, when goods distribution is based on distribution centre, the same company does all processes. However, every process connected with goods flow is exposed to different deviations. That deviations are called disruptions, and enterprise, in this case distribution centre, should focuses on their compensation.

\section{Compensation of disruptions}

Disruptions, apart their kinds, are the results from different causes. There are 4 main sources of disruptions: processes, suppliers, customers and organization/control (Kramarz, 2013, p. 75). Additionally, the potential sources of processes disruptions are events connected with the groups of factors like:

- organizational, specify the development level of logistics systems, their efficiency and effectiveness of management methods,

- technical, which conditioning processes efficiency connected with technology of distribution, reliability of supply and logistics infrastructure, 
- economic, which have influence on physical flow, they slow down, stimulate or initiate the goods movement.

Additionally, that events could be also: operational causes connected with equipment or system errors, natural causes, for example: earthquakes, hurricanes, political instability and terrorism in particular markets which have influence on enterprise (Kleindorfer, and Germaine, 2005, p. 2-3).

Disruptions factors are every unexpected event which:

- has crucial influence on system and causes state changing in this system (Kramarz, 2013, p. 71),

- has destructive influence on system, which implies events far away from state of balance or activity goals (Oke, and Gopalakrishan, 2009, p. 168-174).

In the activity of companies there are a lot of this kind of events. There could be for example: order fulfilment time, lack of qualified employees, safety requirements level, limited communication, demand differentiation, insufficient distribution channels capacity, lack of system control, limited transportation and manufacturing capacity or insufficient quantity of suppliers (Kramarz, 2013, p. 83). A set of many factors which caused disruptions and occurred in logistics processes or systems could be called like disruptions strengthening zone. In different organizations these factors could occur in different probability and disruptions have different results. Therefore, disruptions analysis should be making in each of enterprises individually (Chopra, and Sodhi, 2004, p. 53-61) and every enterprise should prepare individually resistance attributes, too.

In the context of logistics, resistance has a lot of definitions, for example:

- reaction capacity to unpredictable disruptions and reinstatement normally activities (Zaczyk, 2016, p. 584),

- system return to balance state under the influence of disruptions (Kramarz, 2014, p. 45),

- capacity to survive the exposure and keep the continuity of required functions in the acceptable effectiveness and quality level (Kramarz, 2015, p. 183),

- organization's or system's attributes which secure enterprise for negative deviations caused by disruptions (Bukowski, 2016, p. 160).

System, which structure is resistant to disruptions is reliable and allows to quick reaction on disruptions. It could also reduce the disruptions in the way which doesn't cause negative effects in goods flows or financial and organizational loses. Among features, which could improve system's resistance is flexibility. Flexibility means system capacity to change adaptation. Beside this there are others variants like: suppliers or stocks excess. Using this methods to creating resistance could allow to fast network reconfiguration and disruptions impacts reduce. Additionally, activities which allow to improve resistance could be for example: network susceptibility audits in all stages from suppliers to final customers, making 
rigours causes-effects analysis, creating strategically plans, making emergency plans (O’Reilly, 2014).

Different way to resistance rising stimulate could be wide range of using in all processes Internets, satellite networks, radio frequency technology and others, which allow to better information flows and smaller disruptions. However, some of disruptions factors, because of their nature, are tough to predict. Also, majority of disruptions is tough to predict and manage (Hendricks, and Singhal, 2005, p. 36). It could lead to the conclusion that it is impossible to reach the optimal system and processes resistance level, because always will appear new disruptions and system will have to prepare new solutions (Zaczyk, 2016, p. 590). Due to this, huge role in logistics processes has disruptions appearance risk and disruptions compensation. Compensation is one of the risk management strategy appealing to disruptions (Kramarz, 2015, p. 183).

Disruptions compensation is defined like a disruptions results reducing in the goods flows (Kramarz, 2013, p. 29). By compensation the results of disruptions are not spreading all over entities cooperating in the network. Material separation points are mainly responsible for compensation. On the other hand, disruptions occurrence risk includes: probability of disruptions occurrence and their influence (Konecka, 2015, p. 68).

During probability analysis, in the first stage, should be identified that disruption is caused by internal or external factors. Additionally, should be specified as caused by work errors or natural factors. Disruption influence is analysing in the 3 step scale from small to big. Considered factors are for example: enterprise size or disruption type. Disruption creating risk reaches when: supply network globalization, customer market increases and rise of nodes numbers in the network. Additionally, aspect, which could be consider in disruptions analysis, is their influence on enterprise capital risk. It could be measured by internal rate of enterprise capital return.

Among factor which could limit the risk of disruptions occurring there are (Konecka, 2015, p. 75):

- high requirements for supply punctuality indicators,

- choosing the nearest suppliers,

- simplification of orders planning and fulfilling processes,

- current information changing with suppliers and customers about stocks levels,

- sharing information about planning sales in the retails points,

- keeping high quantity of goods suppliers.

Additionally, activities which could reduce risk of disruptions occurring are: reducing bottlenecks and improve flexibility of enterprise (Kramarz, 2013, p. 36). Over the years the problem of disruptions reducing has developed from stock management to strategically level, which includes for example managing the supplier's bases or cooperation with them. Important area which has influence to company activity and which is extremely exposed to 
disruptions is cooperation with suppliers. Failures of suppliers could lead to failures in enterprise activity (Wieteska, 2015, p. 147). One of conceptions to reducing risk of disruptions occurring is supplier's assignment to particular groups. Groups are specified in Kraljic's Matrix. In the next step adjustment activity to proper solution, it is showed in table 3.

Table 3.

Proposed activities to reaction against potential disruptions

\begin{tabular}{|l|l|l|l|}
\hline $\begin{array}{c}\text { Influence to } \\
\text { financial result }\end{array}$ & $\begin{array}{l}\text { Risk connected } \\
\text { with supplies }\end{array}$ & Goods suppliers & \multicolumn{1}{c|}{ Proposed activities } \\
\hline Big & Big & Strategic & $\begin{array}{l}\text { Having an emergency supplier, detail plans in } \\
\text { a lot of possibilities. }\end{array}$ \\
\hline Big & Small & "Levers" type & $\begin{array}{l}\text { Using multisourcing and sending orders to a } \\
\text { lot of suppliers. }\end{array}$ \\
\hline Small & Big & "Bottleneck" type & $\begin{array}{l}\text { Keeping highly safety stocks level. Taking } \\
\text { care of goods safety. }\end{array}$ \\
\hline Small & Small & Standard & Using different sources of supply. \\
\hline
\end{tabular}

Note. Own elaboration based on: "Skuteczne reagowanie na zakłócenia - elastyczny łańcuch dostaw" by G. Wieteska. Copyright 2015, by Uniwersytet Ekonomiczny we Wrocławiu, p. 148.

Conception proposed in the table 3 allows to improve resistance of enterprise to disruptions, which are caused by failures in supplier's systems activities. In the case of key suppliers, this conception could be expensive, but the scale of potential disruptions results, makes them often profitable.

Additional elements of disruptions analysis should focus on the stages like:

- identification of appearing places of disruptions factors,

- identification of elements which are the source of disruptions,

- identification of disruptions,

- identification of loses and deviations caused by disruptions.

Causes-effects relations of deviations, which are caused by identified disruptions is showed in table 4.

Table 4.

Example causes, effects and deviations in goods flow

\begin{tabular}{|l|l|l|}
\hline \multicolumn{1}{|c|}{ Causes } & \multicolumn{1}{c|}{ Effects } & \multicolumn{1}{c|}{ Deviations } \\
\hline - documentary failures, & $\bullet \begin{array}{l}\text { maladjustment the system to } \\
\text { reach the planning requests, } \\
\text { - incorrect IT system, }\end{array}$ & $\begin{array}{l}\bullet \text { decreasing the level of logistics } \\
\text { customer service, }\end{array}$ \\
$\begin{array}{l}\text { - failures or lack of employees, } \\
\text { forklifts or vehicles } \\
\text { breakdowns. }\end{array}$ & $\begin{array}{l}\text { a long time of distribution and } \\
\text { transportation processes } \\
\text { realization. }\end{array}$ & $\begin{array}{l}\bullet \text { incorrect stocks levels, } \\
\text { additional transportation costs. }\end{array}$ \\
\hline
\end{tabular}

Note. Own elaboration.

Causes-effects relation could be created by using for example Ishikawa Diagram. Occurred disruptions levelling could be made by analysis of their sources and deviations types. To identification and measure disruption there is a lot of methods. For example, suitable method to visualization of potential disruptions size could be FMEA and calculation 
of RLF. RLF is a result from multiplication of: importance (Im), probability of occurrence $(\mathrm{Pr})$ and detection (De), so:

$$
\mathrm{RLF}=\operatorname{Im} \mathrm{x} \operatorname{Pr} \mathrm{x} \text { De }
$$

Appropriate methods and procedures selection allows to necessary activities implementation to reduce existing and protect from future disruptions.

\section{Disruptions in distribution network - identification and role of chosen distribution centre}

Entity which is considered in the article is a distribution centre which belongs to distribution centres network works in the Poland. This network supplies the network of retail points. In 2016 one centre flows daily about 4000000 pallets. Area of one centre is average about $400000 \mathrm{~m}^{2}$ and it could be classified like a regional distribution centre. Each of centres work in these same rules.

Due to the fact that distribution centre is distribution network coordinator, disruptions generated in centre have a crucial influence on every entity in mentioned network. Disruptions in goods flows mainly concern supply processes, cooperation with suppliers, warehouse management and distribution processes. In supply area the key disruptions are generated in the order fulfilment stage. To disruptions compensation enterprise is doing the varied policy of stocks management. For mainly goods the rotation of goods is equal 2,3 of day, while for quickly spoil goods is equal 1,1 of day. Relationships with supplier management is extremely important and require large financial contributions. Therefore, in the research centre this process is complex and precisely planned. Distribution centre uses suppliers measure cards, which consist of criteria such as quality, punctuality and reliability. Appropriate departments in company take part in creating relationship with suppliers. They state quantity of goods to order, take care of keeping correct stocks indicators in the warehouse. Suppliers provide goods to centre by using own transport fleet or by forwarders. They are obligated to provide goods in time planned by centre. It is allowed to provide them maximally half hour before or after planned period. In this stage the disruptions are generated, there are on the sides both suppliers and forwarder.

Procedure, which has developed and has used for make results in the identification and analysis of disruptions, consist of methods such as: process map, disruptions measurement card, Ishikawa Diagram and FMEA. Procedure is showed in the fig. 2. 


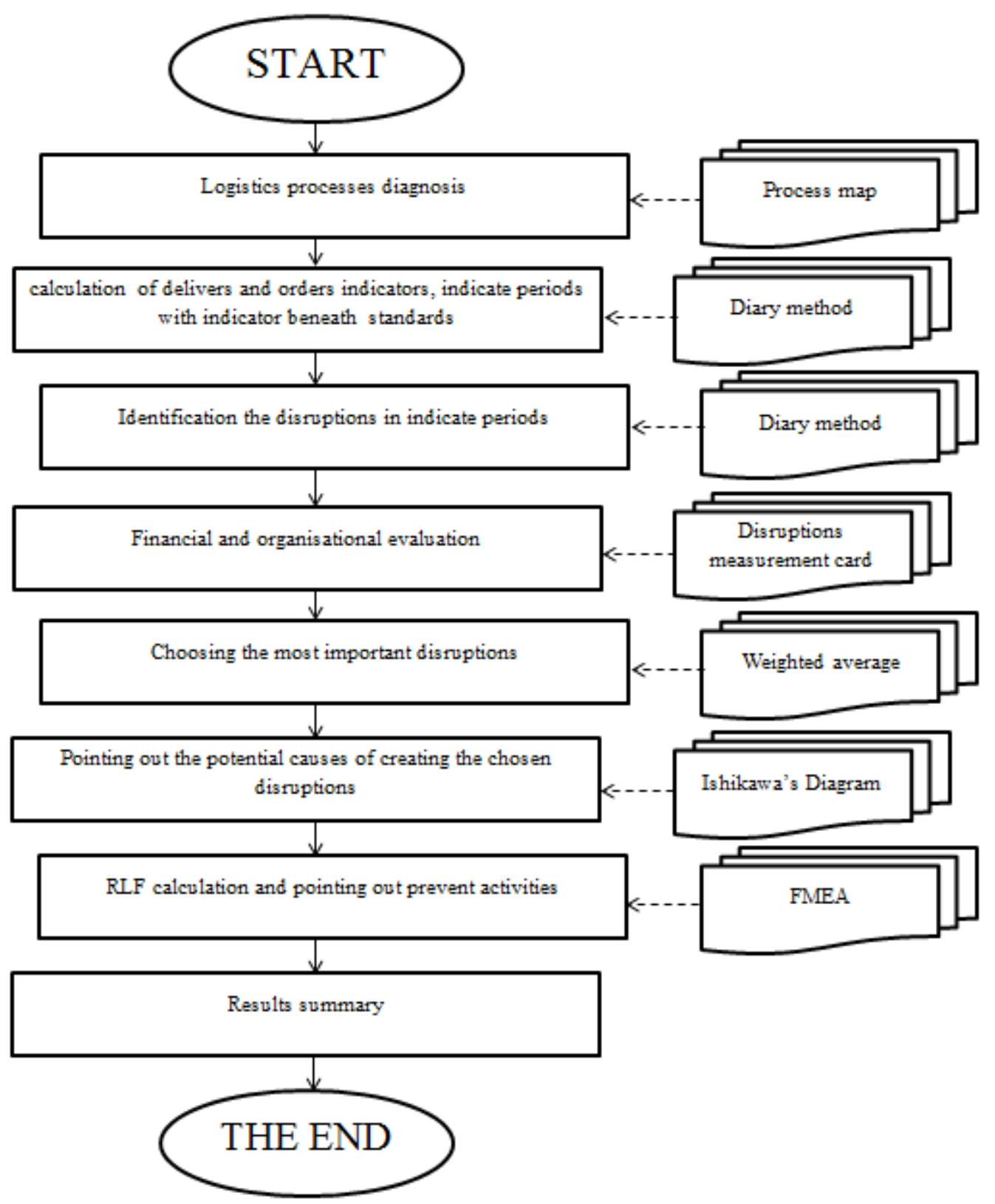

Figure 2. Identification and analysis procedure in distribution network based on distribution centre. Own elaboration.

Showed procedure starts with logistics processes diagnosis by using process map. After taking details about operation in processes, the next step focuses on calculation the deliveries and orders fulfilment indicators. It is need to show level of this indicators which are satisfied for enterprise. In the periods below this level the distortions are identified. Next, disruptions are analysed by disruptions measure card. Analysis contain of financial and organisational assessment in 5 grade scale. Disruptions are rated by using weighted average which consist of following weights: financial rate, organisational rate and number of occurrences. Mainly disruptions should be further evaluation, firstly by Ishikawa Diagram, which potential causes of disruptions are specified and next by using FMEA to show prevent activities. 


\section{Conceptualization of disruptions compensation in distribution network}

Article includes the result of last stage of this procedure. According to FMEA for each of diagnosed disruptions in distribution centre it could be stated that:

- main areas of disruptions origins are activities connected with human's work, using methods, management and using machines and devices,

- disruptions are mainly generated inside the company, so they are result of incorrect run of processes in centre or outside of the company, connected with cooperation with suppliers and sometimes connected with natural causes,

- disruption could cause occurring one or several effects in one time. Effects have different intensity and importance to enterprise,

- for all disruptions could be using prevent actions, which enterprise could implement without breaking the continuity of processes,

- all prevent actions could decrease the level of RLF indicator.

Decreasing the level of RLF by using prevent actions to 3 most important disruptions is showed in table 5 and fig. 3.

Table 5.

Example causes, effects and deviations in goods flow

\begin{tabular}{|l|c|c|c|c|}
\hline \multirow{2}{*}{\multicolumn{1}{|c|}{ Disruption }} & \multicolumn{2}{c|}{$\begin{array}{c}\text { Totally RLF of potential } \\
\text { disruptions causes }\end{array}$} & \multicolumn{2}{c|}{ Cumulative value } \\
\cline { 2 - 5 } & before & after & before & after \\
\hline Lack of goods in warehouse & 2239 & 880 & $58,38 \%$ & $22,95 \%$ \\
\hline Quality reject of delivery & 820 & 263 & $21,38 \%$ & $6,86 \%$ \\
\hline Delay and reject delivery & 776 & 247 & $20,23 \%$ & $6,44 \%$ \\
\hline
\end{tabular}

Note. Own elaboration.

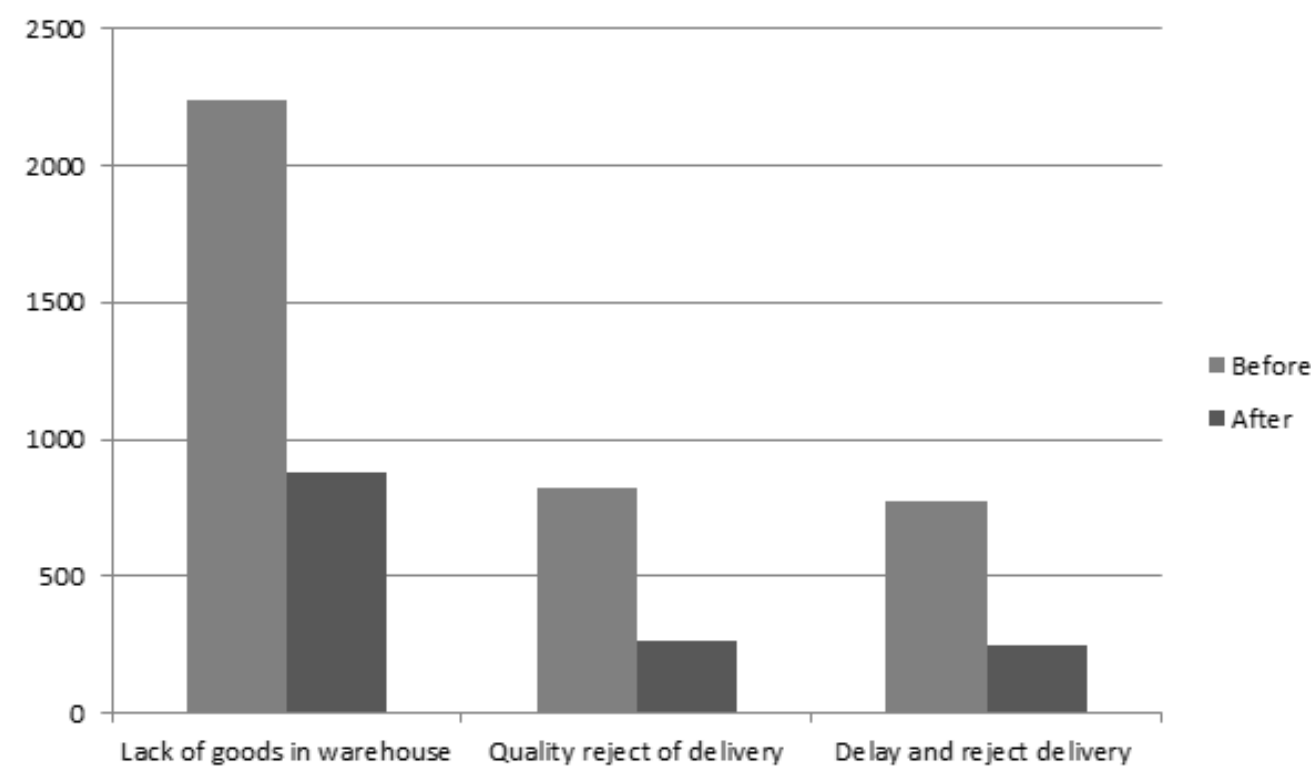

Figure 3. Cumulative RLF quantity for disruptions before and after prevent actions implementation. Own elaboration. 
Compensation of disruptions in distribution centre requires focusing on RLF improvement. Showed improvement could be reach by implement prevent actions which are specified in FMEA. This action mainly focuses on:

- implementation of periodic trainings for warehouse workers,

- enhancement the control of planned works and processes,

- improvement of supplying procedures and increase the flexibility,

- improvement of goods picking procedures,

- taking care about quality of using devices, servicing and frequent exchanges or modernization,

- modifications in IT system,

- improvement of cooperation with suppliers,

- control of supplier's actions, current reporting and taking the consequences,

- increasing flexibility, mainly in reaction to unexpected changes in supplies schedule.

Compensation of disruptions strategy in distribution centre requires firstly: using proper stock management methods, which is varied to particular assortment groups (which mainly concern repetitive disruptions), secondly: taking long-term activities connected with information infrastructure and humans resources management (which allows to more effective reaction to disruptions and reduces the effects of hardly-predicable disruptions) and thirdly: increasing the organisation flexibility and perfecting processes and relations with suppliers (to reduce disruptions). First and second variants are the elements of disruptions compensation strategy, while third applies to disruptions minimization strategy. By the fact that distribution centre is a network coordinator of goods flows it needs to take decisions in extraordinary situations, for example when unexpected disruptions appear and delivery have huge priority for customer. This kind of decisions are extraordinary transport which requires creating the network relationships with transportation companies.

\section{Summary}

Creating the appropriate methods of disruptions compensation for goods flows coordinate enterprise in distribution network is extremely important issue. Properly disruptions reducing could have positive results for both the enterprise which disruptions are concerned and other entities which are taking part in this same distribution network.

The possibility of prevent actions implementations was observed in examined enterprise. These actions could lead to disruptions and their effects reducing. Showing the variants of disruptions compensations required creating the disruptions identification and analysis procedure, too. Disruptions compensation methods could be customized to disruptions 
frequency (predictability) and to effects which disruptions bring to distribution centre and other entities working in the network. Procedure is universally and flexible tool which could be implement in all entities connected with goods and information flows where the disruptions could appear.

It is needed to remember that disruptions are an integral part of company function. Disruptions are integrated element of organisations functioning. They are changing all the time, so the most important thing, if enterprise wants to ensure functioning continuity and competitive advantage, is the constantly creation of distribution network resistance. Creating resistance consist of periodic analysis of potential disruptions to compensate them.

\section{Bibliography}

1. Baker, P. (2008). Aligning distribution centre operations to supply chain strategy. International Journal of Logistics Management, Vol. 15(1), p. 9-15.

2. Baker, P. (2007). The role, design and operation of distribution centres in agile supply chains. Cranfield University School of Management, p. 14-15.

3. Barcik, R. (2005). Logistyka dystrybucji. Bielsko-Biała: ATH.

4. Bendkowski, J., Kramarz, M., and Kramarz, W. (2010). Metody i techniki ilościowe w logistyce stosowanej. Wybrane zagadnienia. Gliwice: Politechnika Śląska.

5. Bendkowski, J., and Kramarz, M. (2011). Logistyka stosowana metody, techniki, analizy, cz. 1 i cz. 2. Gliwice: Politechnika Śląska.

6. Bukowski, L. (2016). Zapewnienie ciagłości dostaw w zmiennym i niepewnym otoczeniu. Dąbrowa Górnicza: WSB.

7. Chopra, S., and Sodhi, M. (2004). Managing Risk to Avoid Supply Chain Breakdown. MIT Solan Management Review, Vol. 46(1), p. 53-61.

8. Grabowska, J. (2008). Wpływ funkcjonowania centrum logistycznego na modernizację kanałów dystrybucji. In J. Bendkowski, Wybrane elementy zarządzania logistyka $w$ przedsiębiorstwie. Gliwice: Politechnika Śląska, p. 34-35.

9. Harps (2005). Best practices in today's distribution centre. Retrieved from www.inboundlogistics.com. Available online 09.08.2017.

10. Hendricks, K.B., and Singhal, V.R. (2005). An empirical analysis of the effect of supply chain disruptions on long-run stock price performance and equity risk of the firm. Production and Operations Management, Vol. 14, p. 36-38.

11. Jezusek, M., and Widera, R. (2001). Uwagi do metodologii projektowania strategii centrów dystrybucji. Logistyka, no. 2, p. 16-17.

12. Kleindorfer, P.R., and Germaine S.H. (2005). Managing disruption risks in supply chains. Production and Operations Management, Vol. 1, p. 2-3. 
13. Konecka, S. (2015). Determinanty ryzyka zakłóceń w łańcuchu dostaw. Prace Naukowe Uniwersytetu Ekonomicznego we Wrocławiu, no. 382, p. 68-75.

14. Kramarz M. (2014). Elementy logistycznej obstugi klienta w sieciach dystrybucji. Pomiar, ocena, strategie. Warszawa: Difin.

15. Kramarz, M. (2015). Klastry i sieci dystrybucji we wzmacnianiu odporności i adaptacyjności łańcucha dostaw. Zeszyty Naukowe Politechniki Śląskiej, no. 78, p. 183.

16. Kramarz, W. (2014). Kompensacja zakłóceń w łańcuchach dostaw. Przegląd Organizacji, no. 3, p. 29.

17. Kramarz, W. (2013). Modelowanie przepływów materiałowych w sieciowych łańcuchach dostaw. Odporność sieciowego łańcucha dostaw wyrobów hutniczych. Warszawa: Difin.

18. O'Reilly, J. (2014). Risk Mitigation: Supply Chain Safety Net. Inbound Logistics, January 20.

19. Oke, A., and Gopalakrishan, M. (2009). Managing disruptions in supply chains: A case study of a retail supply chain. International Journal of Production Economics, Vol. 118(1), p. 168-174.

20. Robinson, A. (2015). The most important distribution centre metrics to track and understand. Retrieved from www.cerasis.com. Available online 09.08.2017.

21. Śliwczyński, B. (2008). Planowanie logistyczne. Poznań: Biblioteka Logistyka.

22. Wieteska, G. (2015). Skuteczne reagowanie na zakłócenia - elastyczny łańcuch dostaw. Prace Naukowe Uniwersytetu Ekonomicznego we Wrocławiu, no. 382, p. 147-148.

23. Zaczyk, M. (2016). Synchronizacja procesów logistycznych w kontekście niezawodności i odporności systemu dystrybucji wyrobów hutniczych. Zeszyty Naukowe Politechniki Śląskiej, no. 89, p. 584-590. 